\title{
Nem Deus, nem amo, nem marido: uma trajetória do feminismo na Argentina - entrevista com María Luisa Femenías
}

\author{
Carmen Sílvia Moraes Rial \\ Universidade Federal de Santa Catarina \\ Miriam Pillar Grossi \\ Universidade Federal de Santa Catarina
}

\begin{abstract}
María Luisa Femenías, uma das principais filósofas feministas argentinas contemporanêas, participou da conferência de abertura do congresso internacional Fazendo Gênero 8, no frio de agosto de 2008, em Florianópolis. Coincidentemente, encontramo-nos em março de 2009 no Beatrice Bain Research Group - BBRG, do Departamento de Gênero e Estudos da Mulher, da University of California, em Berkeley, onde estávamos as três como pesquisadoras visitantes. María Luisa (Buenos Aires, 1950) é professora da Universidad Nacional de La Plata e da Universidad de Buenos Aires. Fez seu doutorado com Celia Amorós Puente na Universidad Complutense de Madrid e atualmente é diretora do Centro Interdisciplinario de Investigaciones en Género da Facultad de Humanidades y Ciencias de la Educación da Universidad Nacional de La Plata. Autora de livros sobre o pensamento de Aristóteles, o feminismo na América Latina, o pensamento de Judith Butler, as teorias pós-coloniais e a violência, María Luisa reflete, nesta entrevista, sobre o desenvolvimento do movimento feminista e dos estudos de gênero na Argentina. Além de contar sua trajetória intelectual, María Luisa analisa a história do feminismo e dos movimentos de mulheres na Argentina, em diferentes momentos históricos, defendendo que a teorização acadêmica é fundamental para a própria transformação da sociedade.
\end{abstract}

Copyright $\odot 2009$ by Revista Estudos Feministas 
Miriam Pillar Grossi (MPG): Gostaríamos de começar por tua trajetória acadêmica e pessoal. Como chegaste ao feminismo?

María Luisa Femenías (MLF): Na verdade é um caminho que posso reconstruir agora e que me parece coerente, mas quando comecei não sabia para onde me levava. Eu terminei o curso de Filosofia trabalhando em filosofia clássica, fundamentalmente Aristóteles. Trabalhei pelo menos oito anos estudando Aristóteles, sobretudo a filosofia da linguagem e a relação com a metafísica de Aristóteles, inclusive tenho publicações, um livrinho Como ler Aristóteles. E eu pensava que minha carreira se limitaria aos estudos clássicos. Um ano houve uma convocatória para um colóquio de estudos clássicos, de um simpósio de estudos clássicos, sobre a mulher na Antiguidade. Então, eu pensei que a única coisa que poderia escrever sobre o tema - não sei nada sobre a Tragédia, não sei nada sobre as deusas, não sei nada sobre as musas - era o que dizia sobre a mulher o único filósofo que eu trabalhara. Então, fui aos textos com toda minha ingenuidade, como pode ir alguém absolutamente ignorante de qualquer perspectiva de gênero, que nem sabia que existia nessa época, que já existia há muitíssimos anos, mas que eu ignorava, e me pus a ler e não podia crer no que estava lendo. Então, fiz um trabalho, bem coerente, simples, porque era o que podia fazer naquele momento, e o li no simpósio de estudos clássicos e me convenci de que deveria ser um trabalho muito ruim, pois senhoras e senhores se levantavam empurrando a cadeira (e faziam muito barulho) e batiam a porta quando saíam. E eu o lia cada vez mais preocupada com a qualidade do trabalho e com 0 papelão que estava fazendo, e terminei, creio, com uma angústia muito grande pela reação que tinha havido, convencida de que era a má qualidade do trabalho. E, então, levantei a vista e vi três senhoras, com chapeuzinhos, não me esqueço nunca, que aplaudiam calorosamente, que se aproximaram para me felicitarem pela minha valentia. Não era um ato de valentia, era um ato de grande ignorância. Elas disseram que eram professoras de Filosofia, que tinham trabalhado muitos anos com teorias de gênero e era a primeira vez que alguém se atrevia a apresentar algo - bem, disseram que eram feministas, pois era o vocabulário daquela época falando das mulheres na Antiguidade, que queria ver o lugar que ocupavam em vez de falar das deusas, das musas ou de sei lá o quê. Estavam muito contentes, me convidaram para tomar um café. Eu conversei com elas, me pareceram encantadoras. E quando voltei do congresso, isso era em Tucumã, na Universidade de Tucumã, me preocupei em me inteirar do que estavam falando porque eu não tinha muita ideia. E, então, abandonei a filosofia clássica porque comecei a descobrir um mundo que me explicou muitas coisas de mim mesma e muitas 
coisas que me rodeavam. E afortunadamente, graças a uma situação fortuita, que foi a visita de Celia Amorós Puente em Buenos Aires, que me permitiu assistir a seu seminário, em que fiz duas ou três perguntas de ignorante e que lhe interessaram, o que me levou a fazer depois o doutorado com ela na Espanha sobre uma leitura a partir do feminismo do sistema aristotélico, não somente da Ética, mas do sistema. E esse foi um caminho que não pude abandonar, pois cada vez que encontro uma articulação me parece muito mais explicativa do que as outras teorias filosóficas clássicas que não abandono, que sigo lendo, mas que ponho em polêmica sempre com o feminismo e as teorias de gênero.

MPG: Quem eram essas três senhoras? Eram mulheres conhecidas?

MLF: Uma delas era Lucía Piossek Prebisch, que foi a esposa de um professor muito conhecido, Hernan Zucchi, especialista em filosofía clássica que, suponho, tenha ido acompanhar o evento, casualmente. Lucía Piossek tinha trabalhado muitos anos sobre Simone de Beauvoir, já tinha publicado em Sur, a revista de Victoria Ocampo, alguns trabalhos bem interessantes, objetando filosoficamente a ideia de sujeito autônomo e autoconstituinte, pois era já casada e tinha alguns filhos, e dizia que nenhuma mulher que tenha participado da criação de uma criança podia acreditar em um sujeito autônomo ao modo cartesiano, digamos, mas que tinha que se levar em conta o sujeito relacional, que te introduz no mundo da cultura, no mundo da vida, valorizando positivamente o plano dos afetos. Uma era ela, as outras não sei quem eram. Disseram-me os seus nomes, mas não os guardei.

MPG: Isso foi quando?

MLF: Isso foi quando estava começando a democracia, em 1986. Antes disso eu já era professora de Filosofia, mas comecei a trabalhar na Universidade com o início da democracia. Em 1984, convocam um conjunto de professores e professoras novas. Entro nessa equipe e começo a trabalhar com a professora Margarita Costa em Introdução à Filosofia. E realmente o fato de estar no meio acadêmico me deu a possibilidade de fazer o que os norte-americanos chamam de um fresh start, de começar de novo; porque era a democracia, estávamos cheios de ilusões, havia a possibilidade de mudar e de propor coisas novas. Então, podíamos estar dentro da Universidade, com um grupo de professoras mais velhas, algumas que haviam sido ex-professoras minhas, e criamos um grupo que se chamou Associação Argentina de Mulheres em Filosofia. Começamos a introduzir os temas e os problemas teóricos da perspectiva de 
gênero e tratamos de estabelecer algum laço com o movimento de mulheres, pois o movimento de mulheres tinha ficado completamente proibido durante a ditadura, porque não havia a possibilidade de reuniões. $O$ grupo de mulheres que havia teve que se dissolver, muitas foram ao exílio. Havia, como em tantas coisas na Argentina, uma descontinuidade que queríamos salvar. Tratamos de gerar um grupo teórico com a convicção de que nada resolve melhor os problemas práticos que uma boa teoria. Então, nos pareceu que todas essas reivindicações, que eram importantes e necessárias, tinham que ser apoiadas teoricamente, acompanhando argumentativamente todas essas reivindicações. E foi uma associação que durou dez anos. Fizemos uma revista acadêmica que se chamou Hiparquia, mulher que foi a única Diretora da Academia Platônica - com isso já pode se perceber que muitas de nós éramos de estudos clássicos. Escolhemos o nome para mostrar que também na Antiguidade havia outro tipo de situação para as mulheres, pois nos transmitem uma história com a exclusão de mulheres. Isto não é assim, pois, quando se pode pesquisar historicamente, aparecem muitas mulheres que parecem invisibilizadas, silenciadas, desconhecidas, ignoradas. Então, parece que não tinham nunca existido. E se gera esse efeito de começar sempre de novo, sempre do zero, porque antes não havia. E isso é falso, houve muitas, nós não sabemos que existiram porque nos transmitem uma história sem elas. Então, um dos objetivos foi mostrar que elas existiam e tratar de gerar uma recuperação das vozes históricas das mulheres, além de fazer teoria atual, sobretudo na teoria ética e política como mais urgente. A revista durou dez anos, creio que foi importante, interessante, fizemos algum trabalho próprio e bastante trabalho de tradução e de colaboração com acadêmicas estrangeiras, principalmente para que a academia argentina visse que isso estava legitimado em outros países e que era parte de sua ignorância desconhecer que existia, que merecia ser conhecida e que podia dizer coisas realmente interessantes. Creio que nesse sentido a revista cumpriu um objetivo importante.

MPG: Isto aconteceu nos anos 1980. As filósofas eram a vanguarda dos estudos de gênero e feminismo ou havia outros grupos? Como se desenvolveu esse campo de estudos de gênero na Argentina?

MLF: Havia outros grupos. Na Argentina, se desenvolveu, creio, em vários sentidos. A reforma da Constituição de 1994 foi uma cristalização legal de mudanças muito importantes na situação da mulher. Uma mudança muito importante ocorreu em 1986, quando se sancionou a lei do divórcio. Na Argentina não havia divórcio, então, creio que mais de um terço do país estava em situação de ilegalidade. Havia crianças que não tinham status 
legal e eram consideradas filhos naturais. Como se houvesse filhos que não fossem 'naturais', nasceram como? Não sei! A maior parte das uniões de fato tinha uma duração maior do que os matrimônios originais, muitos dos quais tinham durado um ano, meio ano às vezes, e as uniões de fato tinham 12, 15 anos, estavam estabilizadas. Então, isso foi um ganho muito importante: a lei do divórcio. E que foi bastante difícil de conseguir. Outra conquista foi a equiparação dos filhos matrimoniais e extramatrimonais, porque continuava como uma problema pendente a enorme quantidade de filhos extramatrimoniais nascidos antes da lei do divórcio, filhos extramatromoniais de muitos senhores que não queriam se fazer responsáveis dos filhos que tinham tido fora do seu casamento. Em consequência, essa foi uma conquista muito importante, pois permitiu a pátria potestas compartida, com igual direito à herança. Isso equiparou a situação de muitas jovens e de muitas pessoas na Argentina e deu os mesmos direitos às mulheres que não tinham os varões, pois a lei anterior dava todos os direitos aos varões e quase nenhum direito às mulheres. Por exemplo, antes dessa lei, só os pais podiam dar autorização para sair do país, escolar, não as mães. Então, isso gerou para as mulheres que tinham filhos uma situação muito diferente em relação aos seus filhos. Por outro lado, se admite, a partir da Constituição de 1994, toda união civil de fato. Se chega há alguns anos a uma reivindicação dos grupos de gays e lésbicas na Argentina, à legalização de uniões civis para pessoas do mesmo sexo, que também teve muitas idas e vindas terríveis, com a oposição muito forte da lgreja e de setores que não se consideram membros da Igreja, mas que igualmente apoiam posições muito conservadoras a respeito disso. Também houve a possibilidade de troca de nome, isso foi uma reivindicação muito importante. $E$ creio que nisso a ação das mulheres advogadas e de juízas foi muito importante e o papel da associação de mulheres advogadas feministas também. E das juízas está sendo, à medida que as mulheres vão ocupando lugares e, em consequência, podendo argumentar e sustentar isso. Para modificar as leis, foi muito importante a ajuda de certos grupos de sociólogas e, em menor medida, de antropólogas, e uma expansão muito grande dos estudos de mulheres e de gênero já a partir dos anos 1990. Quase todas as universidades foram consolidando centros de estudos, institutos, comissões de estudos sobre os direitos das mulheres, em que se adotaram diferentes posições: desde os grupos claramente de reivindicação feminista e de gênero até as mulheres que fizeram história das mulheres, sem uma grande perspectiva feminista e de gênero, mas que contribuíram para iluminar com trabalhos realizados por mulheres em épocas em que essas mulheres eram totalmente invisibilizadas. Creio que, neste momento, quase todas as universidades na Argentina, para não dizer todas, têm centros ou institutos, ou equipes de 
investigações teóricas com derivações práticas, com aplicações na sociedade, com assessoramento, com estudos. E acredito que há uma proeminência dos grupos de literatura, a literatura de mulheres etc. Isso tem vantagens e desvantagens. A vantagem é que há uma visibilização forte dos trabalhos das mulheres, dessa problemática. E a desvantagem é que essa visibilização forte leva, às vezes, a certa trivialização. De repente muitas pessoas tratam esses temas de maneira trivial. Não me refiro às mulheres que investigam, me refiro à mídia, me refiro ao tratamento cotidiano dos temas. Se visibiliza, mas parece que se crê que, para fazer algo mais visível, é facilitá-lo e fazê-lo menos complexo. Quando se diz "não se pode dar densidade", mas creio que é um risco que tem que se assumir para que se expanda. Primeiro se sofre uma etapa de trivialização e depois se vê que isso é algo mais do que dizer que mulheres e varões são sem gênero, ou o "as" e o "os", ou usar arroba para não usar o "os", e a que critérios se inscrevem. Parece-me importante, além disso, que muitíssimos temas se debatam e muitíssimos temas se coloquem no tabuleiro. Cria-se, creio, uma possibilidade de discussão argumentada de problemas que nos competem a todos. E aí vejo pelo menos dois problemas: pareceme que há um forte compromisso dos meios de comunicação e de alguns jornalistas que isso não seja uma mera manchete sensacionalista, explosiva. Há algumas jornalistas que fazem bons artigos de fundo, encontram os temas e mostram os problemas, e isso é importante, mas ao mesmo tempo, devido à visibilização, há uma forte reação de certos setores. Quando digo certos setores, me refiro a certos setores da Igreja. A Igreja não é monolítica em nenhuma parte do mundo, e na Argentina tampouco, certos setores que têm poder e que têm maior visibilidade que outros setores geram discursos contra, slogans muito redutíveis, muito reducionistas, mais chocantes do que qualquer discurso, mais desagradáveis do que qualquer discurso. Mas tem como contrapartida um grupo muito interessante de teólogas feministas que trabalham lutando argumentativamente contra a estrutura patriarcal de sua própria lgreja.

\section{Carmen Rial (CR): Elas estão organizadas em um grupo?}

MLF: Sim, é um grupo, eu conheço várias delas. Publicam uma revista que se chama Teologanda, que é de teologia feminista. Têm muitas conexões com a Alemanha, fizeram congressos, realmente têm uma capacidade de trabalho e de produção muito interessante. Eu não sou uma pessoa crente, mas me parece que se atrever a formar um grupo desse nível, primeiro desse nível acadêmico, e dessa potência, dentro da estrutura da Igreja, que é uma estrutura patriarcal por excelência, pelo menos a Igreja Católica da Argentina, é de muita valentia, de muita coragem, de muito impulso. Realmente creio que dinami- 
za muitíssimo o que é a sua própria estrutura. E dialoga muitíssimo com outros grupos teóricos, práticos e empíricos, feministas e de gênero, uma coisa bastante global. E a nós, particularmente, todas as mulheres, creio que nos ajudou muito que nesse momento na Corte Suprema haja uma mulher feminista, que é Carmen Argibay, feminista e que se declarou feminista, o que gerou comentários e epítetos nada agradáveis, e que, além disso, tem proferido sentenças, situações que chegaram à Corte Suprema, sentenças muito importantes. E creio que, para as lutas de gênero, em geral, por ela estar na corte, assim como Eugenio Zaffaroni, é muito importante. Porque eles tomaram posições, tiveram consciência do que significa estar simbolicamente na estrutura patriarcal e apoiaram não só reivindicações, mas muitíssimas situações de juízo estancadas e deram curso e um respaldo sumamente progressista.

\section{CR: Quais são os temas que têm sido debatidos?}

MLF: Uma das coisas que me parecem importantes e que entraram no debate é o tema da violência, a violência contra as mulheres, sobretudo para romper certos mitos, por exemplo, que "a violência contra as mulheres é um problema só dos pobres". Ora, se ascende na pirâmide social, e a violência contra a mulher apresenta as mesmas percentagens. Encobre-se mais, justifica-se de outra maneira, mas não diminui a percentagem. E isto é algo muito importante. Outro tema de debate foi o da ruptura com a ideia de sexo binário, excludente e exclusivo. $\mathrm{E}$ tudo o que isso mobiliza para o debate público e teórico me parece que também é importante e tem se visibilizado muito nos últimos tempos, sobretudo com a lei da troca de nome, com a possibilidade de uniões civis, com a possibilidade de que certos temas "tabus" possam ser ditos, explicados e argumentados. Há tomadas de posição que não devem ser "me parece que", mas que precisam ser argumentadas, mostradas, discutidas. E tenho que contar com uma bateria teórica que é o que fazemos em Filosofia e teorias e mostrar que há muitíssimos matizes que temos que encarar, ignorá-los não os soluciona. Ignorar os problemas, as situações, o que passa no mundo e o que passa no país não soluciona, agrava. Temos que encarar a partir das teorias, das práticas, dos planos de saúde, desde os planos de apoio familiar e social, desde todos os lados em que se possa fazer. Eu, como sou filósofa e me dedico à teoria, digo que posso apoiar teoricamente alguma coisa, outras não posso.

CR: Você poderia fazer uma retrospectiva do movimento feminista na Argentina em contraposição com a história argentina? 
MLF: Nossa história é uma história impregnada de hiatos, de rupturas, de cortes. Para fazer uma história do movimento feminista na Argentina, preciso primeiro esclarecer que não sou historiadora, falo conceitualmente como filósofa que pesquisou o movimento feminista na Argentina. Creio que primeiro e principal é preciso remontar ao último terço do século XIX para começar a ver o trabalho feminista em três grandes grupos. Nós que chamamos na Argentina de liberais (que não são os que são os liberais americanos, nós temos categorias econômicas e de direito), nos grupos de mulheres socialistas e os de anarquistas. Liberais e socialistas apoiam, desde os finais do século XIX, a reforma do Código Civil e as reivindicações de iguais direitos de cidadania, iguais direitos de educação, iguais salários, trabalho igual. Isso no século XIX está nos textos. As anarquistas tinham o slogan "nem deus, nem amo, nem marido", com o qual proclamavam o "amor livre" no século XIX e tinham um jornal que se chamava $A$ Voz da Mulher, o qual assinavam com um pseudônimo, obviamente porque, dadas as condições da época, não podiam assinar com os seus nomes verdadeiros. Eu as leio com carinho, pois me parece um grupo de mulheres absolutamente valentes, absolutamente progressistas, à frente há décadas, muitas décadas. Por sorte podemos lê-las graças ao trabalho de um colega que já se iniciou há um par de anos, Oscar Terán, que recompilou todos os exemplares dA Voz da Mulher, exemplares com quatro páginas, quase um folheto, em um livro que se chama precisamente $A$ voz da mulher e que está em fac-símile com todos os escritos dessas mulheres. Visto hoje, mais de 100 anos depois, é sumamente interessante lê-las. É curioso, pois não querem ser feministas, pois feminista é uma palavra burguesa. Então, provocam as socialistas e as liberais por serem burguesas - elas quase todas são operárias ou professoras de escola elementar que se consideram operárias, ou trabalham em fábricas de cigarros, ou são passadeiras, ou são lavadeiras. Dizem que o feminismo das socialistas e das liberais é burguês - tem razão, por outro lado -, portanto, não querem se reivindicar como feministas.

\section{MPG: Elas se chamam como?}

MLF: Elas se chamam só "mulheres" e alcunham esse slogan de "nem Deus, nem amo, nem marido". E a primeira coisa que fazem é reclamar a seus revolucionários (porque têm companheiros de rota, maridos anarquistas) porque querem fazer a revolução no espaço público e não fazem a revolução em casa, criando dos filhos, ou lavando a louça, ou retirando o lixo - as coisas, digamos, do espaço doméstico -, porque não se encarregam disso. É muito interessante. Evidentemente, $A$ Voz da Mulher foi fechado. Em 1905 se proclamou o que se 
chamou a Lei de Migrações, lei de estrangeiros, não recordo o número, e se expulsaram todos os anarquistas homens e, suponho, também as anarquistas mulheres. O que ocorre é que não há os mesmos registros para as mulheres. Sabem-se quantos anarquistas foram expulsos pela lei de estrangeiros, mas não se sabe exatamente o número de mulheres, pois não há registro.

CSR: Eram de origem italiana?

MLF: Praticamente quase todos os anarquistas eram de origem italiana. Havia espanhóis também, mas quase todos eram de origem italiana. E havia também russos, que vieram expulsos pelo czarismo, geralmente de origem judaica, e chegaram na Argentina, como poderiam ter chegado em Porto Alegre, Montevidéu ou onde fosse, um porto que os acolhesse, ali ficavam. Então, o grupo de mulheres socialistas era um grupo muito ligado ao partido socialista que fundou Juan B. Justo. Publicavam um periódico que se chamava Nuestra Palavra. Uma das representantes mais importantes era a socialista Alicia Moreau. Sempre se cita Alicia Moreau de Justo, pois ela era socialista e feminista antes de ser "de Justo", por isso sempre a nomeio com o nome de solteira. Entre outras coisas, porque veio de uma família de 'comunitários' franceses, dos que perderam a Comuna de Paris e foram expulsos da França, e alguns acabaram na Argentina, como poderiam ter ido para qualquer outro lugar. Ela nasceu, creio eu, em Londres e veio ainda bebê, mas de uma família francesa, uma família muito militante, de muitas reivindicações e, em algum momento, se aproximou dessa revista, Nuestra Palavra, através de Sara Justo, que é a irmã do fundador do partido socialista. E constitui um movimento de mulheres socialistas muito forte.

E das liberais, muitas são radicais, que vão constituir, mais tarde, o partido Radical, que é um partido de centro. Desse grupo de mulheres as anarquistas já deviam ter sido expulsas. Organizam, conjuntamente, o Primeiro Congresso Feminista Internacional, em Buenos Aires. Em 1899 tinha havido um em Londres e haviam mandado, pagando passagem e os dispêndios, Cecilia Grierson, que era de família inglesa, dominava o inglês, e a primeira médica argentina. $E$, então, mandaram-na como representante, e ela deve ter proposto e ficou acertado que Buenos Aires seria a sede do próximo congresso em 1910. Isso coincidiu com o centenário da Independência e toda a parafernália que isso deve ter significado na época, e as atas existem, de fato, elas foram reeditadas no ano passado, com as temáticas com que foram tratadas nesse primeiro congresso feminista, e são sumamente interessantes. Pude lê-las alguns dias antes de vir à Berkeley, e é sumamente interessante a reedição que se fez na cidade de Córdoba. As temáticas que aparecem são: tráfico de mulheres - que na época se chamava 
tráfico de brancas -; prostituição; saúde da mulher; e sexualidades - que agora chamariam com aspas de "alternativas" e que, na época, aparecem como 'outras formas de vínculo', uma forma encoberta de falar disso, ou seja, lemos esses temas e, claro, podíamos agregar nesse momento tudo o que a medicina e a biologia aportaram como especificidade a certas temáticas, mas há temáticas que seguem vigentes. Realmente é muito interessante, pois há representantes de toda a América, Paraguai, Brasil, Uruguai, Argentina, Chile, ou seja, deve ter sido um evento muito importante, com mais de 300 mulheres, o que, para época, mobilizar-se com esse tema era muito. Com todo esse movimento, conseguem em 1926 igual trabalho, igual salário, o direito a não ter o sobrenome do marido se são profissionais e o direito de administrar os seus próprios bens - porque, de acordo com o código anterior, se elas trabalhavam, o salário era do marido; se tinham herança, era administrada pelo marido. A partir de 1926 são responsáveis por seu próprio dinheiro e por agregar ou não o nome do marido ao casar, se podiam provar que tinham uma profissão. E, de fato, a maioria não o usa, como uma forma de militância. E igual trabalho, igual salário, ou seja, equiparação de salário. Já na Universidade entravam desde o século XIX, pois não havia, nos estatutos universitários, nenhuma regulamentação que proibisse o ingresso de mulheres. Então, entravam, Ihes davam títulos acadêmicos. O problema era depois, quando iam exercitar a profissão: às médicas davam pediatria, coisas vinculadas mais ao assistencialismo, digamos. Às advogadas davam o direito das mulheres, o direito de famílias etc. E havia grandes limitações para exercer a profissão. Então, fundaram a União de Mulheres Universitárias. Ora, o que se passa em 1930: há a revolução, a ditadura chega ao poder e a direita católica, menos progressista, digamos, com todo esse movimento, se não se deslocou antes, se desloca agora totalmente. Tivemos, por um longo período, militares, e, depois, imediatamente, sobe ao poder o peronismo, com o nome de Partido Laborista primeiro e como Partido Justicialista depois. A figura que se reivindica é a figura de Eva Perón. $O$ interessante nessa situação é que se reivindica a figura de Eva Perón. É verdade que Eva Perón, como figura feminina, foi muito carismática e muito importante, porém o peronismo, em geral, não reconhece toda a trajetória socialista, anarquista, radical anterior.

Eva Perón era uma mulher absolutamente carismática, com uma energia muito forte, com uma implícita, eu diria implícita, reivindicação de classe, por pertencimento próprio. Não explícita, pois não há uma teoria de classe, isso não aparece no seu discurso, tampouco tem um discurso feminista. Isso foi muito bem trabalhado por Mirta Lobato, que tem um excelente livro em que discute Eva Perón, ou Eva Duarte de Perón, como se queira dizer, mostra claramente que ela não tem princípios feministas. 
O que tem é um discurso carismático e uma capacidade incrível de se comunicar com as pessoas, de convocar as pessoas. Mas sempre fala em nome de Perón, em nome do general. Então, do ponto de vista estritamente feminista, de gênero, há uma midiatização muito forte de sua figura, que obviamente ganha votos não para ela, não se reverte para ela, mas para Perón, que termina com a vitória nas eleições etc. Então, essa é uma análise a partir de minha posição, por suposição. No discurso peronista o feminismo começa com Eva Perón; há uma espécie de tábula rasa de todas as mulheres anteriores que trabalharam realmente com o feminismo. E a figura de Eva Perón divide o feminismo. Divide o feminismo porque muitas mulheres seguemna e reivindicam-na, ao mesmo tempo que muitas mulheres não apenas não votam nela, como não podem atuar na arena pública porque estão proscritas como antiperonistas. Então, se gerou uma cisão muito forte. Sempre se pode lembrar como caso paradigmático o de Victoria Ocampo. Ela estava totalmente proscrita e, portanto, não podia votar. Ela que era uma lutadora que já nos anos 1930 assina um abaixo-assinado para que o governo militar não derrogasse o Código Civil de 1926 que haviam conseguido as mulheres, ou seja, tem uma longa trajetória. Outras como Alicia Moreau, que também tem uma longa trajetória, também está proscrita, pois está proscrito todo o socialismo, ou seja, são mulheres que foram historicamente feministas, há 30,40 anos, e não só não podiam votar quando se outorga o voto às mulheres, como também eram claramente antiperonistas, pelo modelo que propõe o peronismo. Então, a figura de Eva Perón, carismática, totalmente convocante, gera no feminismo um exercício muito forte. E sempre é um ponto disruptivo, digamos, de debate, de polêmica, de enfrentamento, de discussão. Esse é um ponto muito controvertido, polêmico e que, ainda hoje, gera debates e controvérsias, eu diria, ao menos de palavras, violento. O certo é que se consegue o voto. O que ocorre é que a primeira eleição, creio, se realiza em 1949. No ano de 1952 morre Eva Perón. Em 1955 cai o peronismo e volta o governo militar. E com isso, tudo retrocede. Há um breve momento de governo democrático, depois governo militar, termina o governo militar, ocorre um brevíssimo momento de governo democrático de Campora, depois assume Isabel Perón e o governo militar de novo. Com essas descontinuidades, até para nós, a reconstrução de nossa história é muito problemática, pelas descontinuidades, pela ótica que cada um assume ao relatar a história argentina e porque, em todos os governos militares, a situação das mulheres retrocedeu. Isso foi claro, os retrocessos foram claros. Senão na Constituição que estava suspensa e, portanto, não valia a pena modificá-la, pois os direitos estavam suspensos para todo mundo, de fato, havia fortes retrocessos porque os modelos se faziam cada vez mais fortemente patriarcais, autoritários e vinculados às funções "naturais" das 
mulheres, como a maternidade, o cuidado etc. Depois de o último governo militar ter sido derrotado: a sociedade civil o derrota por um lado e ele se autoderrota por outro ao embarcar na Guerra das Malvinas (que aparece em todos os livros como Falklands Islands), ou seja, há toda uma dissolução quase interna, pois isso foi quase um suicídio. A partir daí se trata de reconstruir a democracia, com todos os vaivéns do processo. Há uma forte reivindicação da figura das Madres da Plaza de Mayo. Eu tenho uma interpretação pessoal: creio que é a radicalização de um discurso. O discurso autoritário dos militares, que tinham o slogan "Sabe você, senhora, onde está o seu filho e sua filha agora?", acompanhado de uma imagem com um dedo em riste, eu recordo perfeitamente, perguntando "Você sabe onde está o seu filho agora?". Então, esse mesmo slogan se reverte porque elas dizem "Eu não sei onde está o meu filho agora, porque meu filho foi sequestrado". Então, esse mesmo discurso da responsabilidade materna é levado ao seu máximo expoente, obrigando os pais e, sobretudo, as mães a cumprirem sua função "natural", a saber, em cada momento onde estavam os seus filhos, e o faziam com relação ao potencial de militância em movimentos "subversivos", mas também se estavam ou não na Universidade ou se haviam escapado para um hotel para ter relações sexuais com quem quer que fosse, ou seja, esse controle não somente para os militantes, mas também moral, num sentido mais pacato da palavra, reverte-se em "Eu quero saber onde está o meu filho agora". Isso pode parecer uma análise muito dura, muito dura porque colocamos toda a responsabilidade nessa figura do amor materno, que não é assumida no discurso do outro e que o colocam no lugar de mãe: amante e cuidadora. Isso tem sido muito objetado na Argentina e tem sido objetado porque se diz que isso lhe tira autonomia, valentia. Eu creio que não, creio que, sim, há um uso do papel da mãe no espaço público e isso é o disruptivo, isso é o transgressor, porque a mãe é levada a perguntar onde está o/a filho/a, por que não está no espaço doméstico. A mãe sai ao espaço público para perguntar pelos filhos, onde estão, por que não estão no espaço doméstico. "Eu não sei onde está". Você entende esse jogo? Então, isso é sumamente disruptivo, porque é levar ao espaço público o mais privado. Claro, eu leio essa atitude a partir do "pessoal é político": isso é pessoal, portanto, é político, portanto, é levado ao espaço público. Eu, honestamente, não sei quantas madres eram feministas e se havia madres feministas. Isso é minha posição. Sim, foi um movimento absolutamente hábil, muito inteligente e muito valente, porque tinha que se sair ao espaço público, numa época em que se matava covardemente, em que te tiravam das aulas, ou te tiravam dos ônibus ou dos trens, e te levavam para perguntar o que quer que fosse. Sim, é um movimento muito forte e muito valente. Não sei se é feminista, eu creio que 
não. Minha posição é que não o é. O estudo de Nora Domínguez sobre a figura maternal o entende mais próximo ao feminismo do que eu o entendo, temos aí distintas posições. Porém, essa figura de mulheres deu muita visibilidade às mulheres na Argentina, ao trabalho das mulheres e à credibilidade das mulheres no espaço público, em nível nacional e nível internacional. E creio que isso foi muito importante para o movimento de mulheres, em geral, e para o movimento feminista, em particular, porque as feministas foram voltando e as que estavam dentro e não sabiam que eram feministas, como eu, foram saindo à rua para um monte de coisas. Tínhamos como uma aura de prestígio que havíamos adquirido pelo prestígio moral das madres e abuelas nesse momento. Porque elas realmente saíram para defender uma causa, eu sempre digo, não saíram os pais, não houve um movimento de padres, houve um movimento de madres, ainda que alguns varões as acompanhassem. Elas saíram com uma fralda (pañal) na cabeça não era um lenço (pañuelo), era uma fralda (paña), porque na época em que saíram não havia na Argentina lenços descartáveis, eram de pano, de trapo -, tradicionalmente foram as mulheres que saíram às ruas. Isso gerou para as mulheres, eu creio, aceitemos ou não, saibamos ou não, um piso de credibilidade que antes não era tão intenso. Por quê? Porque a figura da maternidade, de alguma maneira, tinha um prestígio por si mesmo. E aí se armam as reivindicações pelos direitos das mulheres e dos filhos: a pátria potestas compartida, a igualização dos filhos naturais com os matrimoniais, dos matrimoniais e do extramatrimoniais etc., uma série de reivindicações que se cristalizam a partir de 1986. E isso é muito importante e merece ser capturado, pois é um fenômeno muito complexo, a meu modo de ver. É é nesse momento que há um estado de estagnação, de se chegar a um lugar e ficar estacionado. De plano alto. Havia uma agenda de reivindicações: constituição, direitos civis, direitos de cidadania. E chegamos a uma espécie de impasse, ou seja, havia toda uma série de reivindicações que vinham sendo conquistadas nos últimos anos, a partir de 1984, de maneira escalonada, com ganhos legais. E aqui é que vem minha questão - os filósofos não podem deixar nunca de colocar uma pergunta cética, digamos. Para mim, é muito importante as reivindicações que se cristalizaram em modificações da Constituição, de direito, de Código Civil, de Código Penal etc. Porém, creio que a mudança de um sistema de crenças de uma sociedade vai muito mais além do que as "vanguardas" que modificam a Constituição podem fazer. E tem a ver com usos e costumes. Em usos e costumes há muitíssimo o que fazer, muitíssimo o que debater, muitos preconceitos que temos que reverter, muitos preconceitos que temos que colocar em evidência. $E$ isso é um trabalho muito mais árduo, menos exitoso - porque cristalizar uma lei é exitoso, se vê, ela é posta em papel, fica impressa, todo mundo vê que foi feito. Ir revertendo o sistema de crenças, levar as pessoas cotidianas a revisarem preconceitos, prejuízos, o que 'naturalmente' creem que são as coisas, é muitíssimo mais difícil, muitíssimo mais lento, se vê menos, brilha menos e, creio, é muitíssimo mais 
difícil. Então, esse estado em que parece que não acontece nada, porque se conquistaram certas coisas, tem a ver com esse outro trabalho que é mais invisível, mas que creio ser fundamental, porque os direitos que não se usam se perdem, ainda que estejam na Constituição, se perdem por desuso. Se as gerações de jovem não se dão conta do que podem conseguir, do que podem obter, do que podem seguir aprofundando e reclamando, pouco a pouco essas coisas se perdem. A globalização, em alguma medida, joga contra nós. Joga contra porque gera um desemprego massivo, e as mais prejudicadas no trabalho são as mulheres, sempre, porque gera um conjunto de políticas identitárias, de sobrevivência. Em todos os sistemas identitários, geralmente, as mulheres ocupam lugares desvantajosos. Então, isso é preciso revisar. Creio que, aqui, os meios de comunicação, mais do que a televisão, que é massiva e pública, o sexismo e o racismo da internet, na web, são impressionantes. Todos os joguinhos eletrônicos têm um sexismo e um racismo terrível, e esse é um desafio das novas gerações. Eu não vou a esses joguinhos, porque a mim não dizem nada, são alheios a mim. Mas as novas gerações crescem imersas nisso e crescem nesse racismo, nesse sexismo, nessa discriminação e nessas imagens muito deterioradas de mulher e do que é o outro. E isso, creio, as novas gerações precisam trabalhar muitíssimo e, provavelmente, muitas outras coisas que me escapam, pois eu já não estou imersa nessa cultura jovem. Conquistamos coisas, mas há muito mais para conseguir e fazer. E é um fazer constante porque não podemos sentar e descansar. No momento em que sentamos e descansamos, ficamos para trás de novo (risos). Esse é o desafio de que as novas gerações estão se dando conta e estão fazendo, inclusive com outras categorizações que, para nós, são alheias. A mim, pela idade, digamos.

'María Luisa FEMENÍAS, 1996.

MPG: Poderíamos falar um pouco de tua obra? Qual foi o primeiro livro que escreveste?

MLF: Os dois ou três primeiros trabalhos que escrevi tiveram a ver com leituras, a partir do feminismo, da obra de Aristóteles, porque o conhecia bem. À medida que me inteirava do feminismo e da teoria de gênero, o que melhor podia fazer era aplicar ao que conhecia bem, porque vinha estudando há vários anos Aristóteles. Tenho vários artigos e um livro, que se chama Inferioridad y exclusion, ' que escrevi sobre a base do que foi minha tese de doutorado. Nesse livro trato de mostrar, quiçá um pouco ambiciosamente, o fato de que tanto a ética, como a política, a biologia e a metafísica têm articulações que legitimam e sustentam a inferioridade da mulher. Quase todos os filósofos são solidários na interiorização das mulheres, quer dizer, a inferioridade da mulher não é apenas um problema político, ou um problema ético, ou um problema de concepção da biologia, senão que todos os níveis da filosofia de um filósofo, e tomo Aristóteles como exemplo, são solidários na construção da inferiorização, inclusive o metafísico. Todo mundo me aceita no 
político, e no ético, mas quando passo ao biológico me aceitam menos e quando passo ao metafísico quase ninguém me aceita. Mas estou muito contente porque esse livro é de 1996, tem muitos anos, e as últimas coisas que tenho visto que estão sendo escritas tendem para isso e defendem, por outros canais e com outros argumentos, essa posição. Assim, estou muito contente.

MPG: Este livro é tua tese de doutorado, orientada por Celia Amorós?

MLF: Sim, por Celia Amorós. Eu a reescrevi, pois uma tese é muito pesada, tem muitas citações, muito erudita, muito não sei o quê, e tratei de fazer um pouquinho mais amena, digamos. O livro, que considero meu primeiro em feminismo e teoria de gênero, eu escrevi para entender esse campo e se chama Sobre sujeto y genero: leituras feministas de Beauvoir a Butler. ${ }^{2}$ Eu o publiquei no ano 2000. Eu tinha um projeto de pesquisa que se chamava Las criticas pos-modernas al sujeto moderno, incluindo obviamente as teorias de gênero, no qual eu analiso como se constitui a noção de sujeito na modernidade e as críticas que se fazem dessa constituição da noção de sujeito, a partir de Simone de Beauvoir. Tomo Simone de Beauvoir, a irrupção de todas as teóricas da diferença e as contraponho com a análise que faz Carole Paterman da construção do sujeito no contratualismo - eu havia traduzido esse livro para o castelhano, então, tinha os elementos para incluir a crítica de Paterman. E depois tenho um capítulo que se chama "La irrupción de la diferencia", quer dizer, como surge na Filosofia a ideia de diferença como diferenca ja como difference e de que maneira essa diferença adquire diversas características na escola italiana e francesa, como a entendem as norte-americanas, que é outra coisa etc. E termino com um capítulo, do que conhecia até esse momento, de Judith Butler, que não era muito, ela também não tinha escrito a quantidade de coisas que escreveu até agora, e que era baseado em Gender Trouble. Não havia muitas outras obras dela, a mim não havia chegado e tampouco acho que existiam tantas outras. E desse livro eu gosto muito, porque o escrevi para mim mesma, para entender como era a sequência teórica em torno da noção de sujeito. $E$ essa obra me esclareceu muito. O primeiro destinatário desse livro fui eu mesma (risos), depois vi que interessou outras pessoas também. E agora me pediram para fazer uma reedição, não sei por que esse livro teve tanta atração para os psicanalistas. Assim, a clientela maior desse livro foram os psicanalistas.

MPG: E como na Argentina tem muitos psicanalistas... (risos)

MLF: (risos) Pois é, então, tenho a reedição quase assegurada (risos). E depois, como não sabia nada do feminismo ou sabia 
${ }^{3}$ FEMENÍAS, 2002, 2005 e 2007.

${ }^{4}$ María Luisa FEMENÍAS e Amy OLIVER, 2007a.

${ }^{5}$ FEMENÍAS, 2007b.

${ }^{\circ}$ María Luisa FEMENÍAS e Elida Aponte SÁNCHEZ, 2008. muito pouco do feminismo na América Latina e me parecia importante pensar o feminismo na Argentina em função do feminismo na América Latina, fiz uma compilação que se chamou Perfiles del Feminismo Iberoamericano. ${ }^{3} \mathrm{E}$ quando saiu essa compilação, comecei a receber e-mails de mulheres que diziam que, se saísse um segundo tomo, eu as levasse em conta, pois queriam também escrever. Então, quase me obrigaram a fazer o segundo tomo e depois o terceiro. Agora se publicou uma versão do primeiro volume em inglês. ${ }^{4} \mathrm{E}$ agora as pessoas perguntam "por que tal país não está? Falta tal tema, ou falta tal coisa. Por que não fazes um quarto?", e estou embarcada em um quarto volume, é preciso ter uma convocatória, dar prazos e todas essas coisas. O editor desde Sujeto y genero, de quase todos os meus livros, é um senhor chamado Horacio García, que teve a paciência e a generosidade de me ir publicando. O primeiro livro, Sobre sujeito e gênero, eu levei a varias editoras, que não quiseram publicá-lo, pois o tema de feminismo não se vendia bem. Mas ele me disse que sim, que publicaria.

\section{MPG: Era uma editora que publicava livros feministas?}

MLF: Não, não era uma editora feminista. Mas não sei, sua esposa gostou, a que tinha naquele momento, e acho que isso pode ter influenciado. E ele segue editando minhas coisas. Já não tem a mesma esposa (risos), mas continua me editando. $E$ tenho vendido com certo êxito, por isso ele está feliz.

Outro livro meu de que gosto muito é O gênero do multiculturalismo. ${ }^{5}$ Eu queria fazer uma revisão de posições multiculturais à luz da situação das mulheres, até porque, em uma viagem à Espanha e França, a questão do debate multicultural passava pelo véu usado pelas mulheres muçulmanas, e pensei que a nossa própria sociedade multicultural merecia alguma reflexão. Aproveitei o convite da Coleção de Direitos Humanos, da Universidade Nacional de Quilmes, e o escrevi. Não sei se a maioria concorda com o que eu digo, mas vendeu muito porque é polêmico. Ter tomado como ponto de partida a análise da teoria feminista foi polêmico e, penso, iluminou alguns pontos conflitantes das políticas de identidade. Depois, com uma colega venezuelana, Elida Aponte Sánchez, organizamos uma compilação sobre a violência contra as mulheres que tem sido muito bem recebida. ${ }^{6} \mathrm{~A}$ maioria dos contribuintes é teórica do Direito, mas também há contribuições de filósofas e sociólogas, que mostram os limites da legislação nas práticas cotidianas. Essa tensão gerou muita polêmica em torno do desenvolvimento de políticas públicas para promover a mudança social.

CR: De Beauvoir a Butler quais são as influências mais presentes nos estudos de gênero na Argentina hoje? 
MLF: Hoje, Butler, tudo da teoria queer, da qual se leu bastante. Mais do que a teoria queer, Butler. Muito em traduções. Quase tudo está traduzido, mas eu sou muito crítica com as traduções, pois é muito difícil traduzir. Ela é filósofa, deixe-me evocar o grêmio (risos). E há muitas traduções que perdem um pouco o ponto teórico-filosófico que está em jogo em algumas de suas afirmações. Quando dou algum seminário, sempre coloco os textos em inglês, depois se querem ser ajudados com as traduções que o façam. Mas que tenham o texto em inglês, porque ela faz jogos de palavras que são intraduzíveis. Não sei em português, mas em castelhano são intraduzíveis, como Body that Matters, por exemplo, é intraduzível o jogo de palavras que há entre 'importar' e 'matéria', digamos. Então, sempre apresento os textos originais. E depois se leu bastante Nancy Fraser, que foi várias vezes na Argentina, em teoria política, e ultimamente se começou a ler, não sei por quê, anacronicamente, Catharine MacKinnon. Eu estou surpresa que a estejam lendo agora porque sua produção data de muitos anos, tem muitíssima força, sobretudo por seus argumentos legais. Que agora a estejam lendo mais, pessoalmente, me surpreende. Mas essa coisa da transmissão, Cláudia de Lima Costa os tem bem estudado, são itinerários meio imprevisíveis, às vezes. Eu creio nesse momento que quem tem mais influência é Judith Butler. Da academia anglofônica a mais lida é Butler, sem dúvida. Da academia alemã há muito pouca influência porque são poucas as feministas argentinas que leem em alemão. As teólogas sim, quase todas as teólogas leem em alemão, têm trabalhado com muitos textos alemães traduzidos, para beneficio nosso, muitíssimos textos alemães. A única filósofa que está vinculada a esse grupo de teólogas é Marta Palácios, que trabalhou com Levinas e todo esse tema do outro como mulher, como inescrutável. Mas Levinas escreveu em francês. A influência forte é francófona, mais por Foucault e pelo discurso pósmoderno. E esse discurso pós-moderno se conjuga muito bem com Butler.

A visita de Celia Amorós teve um impacto importante na Argentina, pois, como escreve em castelhano, é mais fácil de ler para todo o mundo. Digo ler, e não entender, pois tem um pensamento muito denso e nem sempre quando a lemos podemos desentranhá-la em todas as suas dimensões, mas teve uma contribuição muito importante na Argentina. Na escola italiana, Luisa Muraro, mais do que Adriana Cavarero, é que Butler cita ultimamente, mas na Argentina teve mais influência Muraro que Cavarero. E isso que Cavarero, em castelhano, já está traduzida há tempos. Sem embargo, ela foi pouco lida. Não sei agora, depois de ter sido citada por Butler, talvez todas estejam procurando ler Cavarero, não sei. Porém, é curioso, porque foi traduzida no castelhano faz muito mais tempo do que foi traduzida em inglês, que faz muito pouco tempo, além 
${ }^{7}$ Beatriz CAGNOLATI e María Luisa FEMENÍAS, 2008. de que todo mundo na Argentina lê o italiano, pois todos, mais ou menos, têm um parente italiano ou um vizinho italiano, então, mais ou menos o entendemos. Sem embargo, tem sido muito mais difundida Muraro, com sua ideia de diferença e de afinamento e, curiosamente, com sua ideia de maternidade, com a qual gera certas intersecções muito curiosas porque segue reivindicando certas figuras que, se poderia dizer, são do pensamento tradicional e não do pensamento feminista, como a figura da mãe. Outra teórica de muita influência é Rosi Braidotti, que esteve várias vezes na Argentina e cuja obra mais importante, Sujeitos nômades, se traduziu há bastante tempo. Creio que essas são as correntes que mais influência têm. E a obra de Lola Luna, que é uma catalã, eu pessoalmente conheço pouco, mas sei que teve grande influência nas universidades do norte do país.

Das francesas, tendo ouvido várias vezes falar em Françoise Héritier. Isso levou todo mundo a ler Masculino e Feminismo urgentemente. E foram lidos especialmente pela quantidade de psicanalistas que temos na Argentina (risos). Além dela, Speculum, de Luce Irigaray, o que fez com que tenha havido um impulso de ler a Filosofia desde a psicanálise de Irigaray, o que deixou os filósofos muitos loucos (risos), não gostaram muito. Nota-se muito a influência das leituras de Irigaray. Hélène Cixoux também é lida. Em outros setores mais vinculados à Simone de Beauvoir citam-se Eleni Varikas ou Christine Delphy. Simone de Beauvoir, com o evento do cinquentenário do Segundo sexo e o centenário do seu nascimento - nós mesmos fizemos uma homenagem, colocamos em uma página da web alguns artigos de sua obra,$-{ }^{7}$ se leu muito a sua obra e se tentou fazer uma leitura mais conjunta, não separando o Segundo sexo do que são suas novelas e do que são os seus ensaios. E, assim, creio que ganhou em corpo teórico a abordagem de Simone de Beauvoir, mas isso é mais recente e veio, sim, da academia. E veio unido, quase sem saber, com as feministas 'velhas' dos anos 1960, que tinham como livro de cabeceira o Segundo sexo porque obviamente toda outra produção não seria editada. E isso é interessante.

Eu, em meus seminários, introduzo Christine Delphy porque me interessa muitíssimo que haja uma leitura de feminismo marxista ou, digamos, de marxismo feminista, senão estamos no pósmoderno, ou em modelos mais ou menos "liberais", ou em clássicos como é Simone de Beauvoir, que apresenta várias ideias no Segundo sexo, mas não chega a desenvolvê-las. Então, me parece muito importante que se leia Christine Delphy porque lhe devemos a maior parte das reivindicações trabalhistas e a visibilização do trabalho das mulheres. Na década de 1970, por exemplo, desenvolve as categorias de "trabalho invisível", redefine "trabalho", mostra como as estatísticas, que, então, não distinguiam sexo nas porcentagens que elaboravam, encobriam a diferença econômica existente entre homens e mulheres. 
CR: Em Berkeley, o que temos visto se praticar, especialmente por jovens lésbicas, é a transformação corporal, o cross-gender. Como tu pensas a questão transgênero?

MLF: A excessiva medicalização de qualquer corpo me preocupa, porque há toda uma manipulação desse corpo, em muitos sentidos. E isso é um problema, sobretudo, quando as pessoas estão fora do sistema de saúde, estão excluídas do sistema de saúde, ao menos nas práticas.

CR: Temos que reconhecer que há hoje reivindicações de teóricas de gênero para ficar fora do sistema médico hegemônico. Os transgêneros dizem evitar, assim, um controle sobre o seu corpo. Mas não acho que o Estado possa se desobrigar...

MLF: Esse é o problema, o Estado se descompromete em atender a certos casos, por exemplo, na Argentina, paradigmaticamente, o Estado se descompromete em intervir, ainda que a lei e a Constituição avalizem, nos casos de aborto. A lei garante o aborto, mas uma mulher quando vai a um hospital público, o médico, que tem obrigação legal de realizar o aborto, alega oposição de consciência. Assim, tudo vai ao poder judiciário, quando termina o circuito judicial, a mulher está grávida de cinco ou seis meses e já não pode mais abortar. Isso é um fechamento. É obviamente uma forma indireta de captura desses corpos, dessas pessoas. Sobre controlar o seu próprio corpo, é verdade que se pode fazer em algumas circunstâncias, mas não em circunstâncias de enfermidade, por exemplo, em uma peritonite ou em uma síncope, não. E quando não há cobertura, não há cobertura para nada. Não apenas para controlar se tomo ou não tomo, mas para coisas muito mais graves. Esse é um problema parecido com o das mulheres em situação de prostituição. Vão aos hospitais públicos e não conseguem atendimento, 'não por isso', 'não por aquilo', ou seja, apesar de as leis existirem, no nosso país a lei existe, apesar de os planos de saúde existirem e contemplarem o atendimento - são, de certa maneira, progressistas -, o problema é a aplicação. Porque diante da "objeção de consciência", que é massiva, ficam desamparadas e não há uma punição por "desatenção de paciente" ou por "abandono de pessoa" quando se alega objeção de consciência.

\section{MPG: Como é a lei de aborto na Argentina?}

MLF: Na Argentina há uma lei que autoriza o aborto no caso de uma gravidez não desejada (prostitutas, estupro, por exemplo), de risco de morte para a mãe, de incapacidade da mãe caso seja menor de idade ou incapaz, por exemplo. Já a Constituição dita Velha, o Código Civil antigo, pois houve uma refor- 
ma em 1994 e depois, posteriormente, uma nova mudança exclusivamente nesse artigo, permitia que se fosse menor, incapaz ou no caso de violação poderia legalmente abortar. O que aconteceu é que a interpretação dos juízes era tão retrógrada que, em vez de ver a vírgula como excludente, interpretavam como includente e, assim, exigiam que fossem as três coisas ou duas delas. Ora, com isso, praticamente não se autorizava nenhum aborto. A nova Constituição foi mais explícita, incluiu questões de discriminação de gênero, opção sexual, sendo muito mais precisa, explicitando certos temas que antes ficavam englobados e pressupostos, e depois não se cumpriam nunca. Houve um trabalho muito forte dos grupos feministas para que se precisassem certas coisas. Ainda assim, muitos juízes se negaram, com a alegação de objeção de consciência, a autorizar abortos. Houve um caso terrível, terrível, em Salta, na capital da providência de Salta, de uma menina menor de idade que foi violada e, provavelmente, tenha sido abusada sexualmente repetidas vezes pelo patrão da casa onde trabalhava, ficou grávida, nasce a criatura e ela a mata. Tem a criatura no banho e a mata, ou seja, vai a julgamento por assassinato, agravado pelo vínculo, porque era a mãe.

E a imprensa o que faz? Sai com manchetes sensacionalistas, mas raramente aprofunda o problema. Porque aí se faz o teste de DNA, se sabe que o pai é um senhor casado, muito bem situado, muito digno, muito honrável. E ele não tem responsabilidade nenhuma. O senhor não tinha nada a ver, pois, afinal, foi a menina quem matou. E como era menor, mas não tinha menos de 16 anos, então, o caso é moderado, já não é considerado violação, pois há outra figura legal que não sei exatamente qual. Daí já é com consentimento, diminuindo a responsabilidade dele. Ele não ficou na cadeia nem dois dias. Agora, não se levam em conta fatores de poder. Nessas sociedades não somente patriarcais, mas feudais até, claramente, uma pessoa que pertence à classe mais baixa não se contempla o que significa estar na posição debaixo da pirâmide de uma estrutura de poder desse tipo. Portanto, a possibilidade de dizer não é muito limitada. Não se trata de uma pessoa totalmente autônoma que diz "vou procurar trabalho em outro lugar, em outra cidade, vou para outro lado", porque quem pode fazer isso, pode pagar um aborto em um lugar privado, em qualquer lugar, e não vai a julgamento. Quem vai a juízo e pede que o Estado seja o responsável é porque não tem meios. E se expõe ao público e à festa que alguns meios fazem desses casos. Assim, um dos argumentos que usei, em algumas palestras que dei, chamei de 'Direito ao corpo próprio', direito ao poder e de decidir sobre o próprio corpo. Um dos argumentos é o de que certas leis somente prejudicam a quem não tem dinheiro. Quem tem dinheiro vai a uma clínica privada, ninguém lhe pergunta nada, tem tecnologia moderna e pronto. Entra e no dia seguinte 
já sai, nos braços de sua mãe, de seu companheiro, de seu amante, e não acontece nada. Ao contrário, quem não pode pagar isso tem que ir ao hospital público ou à saúde pública, aos sistemas públicos de saúde. Essas são as que pagam todos os preconceitos, nas redes preconceituais, e são apanhadas nas "objeções de consciência" de quem alega não assumir a situação pública de ser responsável por um aborto em uma sociedade muito fechada, na maioria dos casos. É um problema muito complexo: não ter o direito sobre o próprio corpo e não usufruir como uma pessoa, não ser considerada uma pessoa. $O$ primeiro direito de uma pessoa é ter o direito sobre o próprio corpo. Em que sentido estamos falando de pessoa e em que sentido estamos falando de cidadania? Então, aí há problemas muito opostos, com sistemas de valores muito opostos.

Agora, nesse caso, o que está se pedindo é a redução de pena. Primeiro se pediu que não fosse encarcerada, como foi condenada e encarcerada, agora está se pedindo uma redução de pena. Além disso, ela teve problemas psicológicos, infecções, problemas muito sérios. Parece que teve problemas com agressões de outras presas, ou seja, é muito complicado o tema. Noutro caso de violação de uma menina também em Salta, de dez anos, o violador alegou identidade cultural. O violador alega que, em sua cultura indígena wichí, era tradição que as meninas de tal idade, depois de la consecha, não sei o quê, se iniciassem sexualmente, quer dizer, eram iniciadas sexualmente. Portanto, em vez de ser responsável de uma violação, alegava identidade cultural e opunha isso ao direito da criança.

MPG: Mas ela era da mesma etnia?

MLF: Sim.

CR: Ele não foi julgado por sua etnia?

MLF: Houve um julgamento civil, não por sua etnia. Veio um cacique, a chefia do grupo era uma mulher, e essa mulher interveio para dizer que não há nenhuma tradição na etnia que respalde o que fez esse homem. Então, se abriu toda uma discussão sobre o que é identidade cultural, o que determina uma identidade cultural, o que se opõe a quê em caso de identidade cultural, enfim. Resumindo as contas, o juiz determinou em favor do senhor. E aí se fez uma apelação à Corte Suprema. A Corte Suprema, obviamente, revogou a sentença e declarou responsável esse senhor. Qual o problema aqui? O problema é que intervém a corte provincial, corte nacional, há uma ameaça de se ir aos tribunais internacionais, de fazer apelo aos tratados internacionais de San José de Costa Rica, de Belém do Pará, para proteger o direito das crianças. Intervêm 
${ }^{8}$ El caso se examina en Articulaciones sobre la violencia contra las mujeres, de Femenías e Sánchez (2008). os jornais, intervém a comissão da mulher de Filosofia, entrevêm quase todos os agentes sociais ativos em defesa dessa menina. Mas ainda está em apelação, pois quem tem mais poder econômico é esse senhor, está em apelação da apelação. Já se passaram quatro ou cinco anos e ainda não se resolve seu caso. ${ }^{8}$ Na Argentina, a partir dos novos acórdãos (fallos) da Corte Suprema, neste momento duas mulheres a integram, com clara consciência feminista, valorizo muito esse fato. Acho que durante os 25 anos de democracia temos avançado bastante, embora ainda haja muito a fazer. Acho que a democracia reforça o feminismo, e vice-versa. Sem feminismo, sem igualdade, não há democracia que possa portar plenamente esse nome, por isso cada espaço de democratização alcançado é um espaço de consolidação democrática para que todos vivamos melhor.

University of California, Berkeley, março de 2009.

\section{Referências bibliográficas}

CAGNOLATI, Beatriz; FEMENÍAS, María Luisa. A 100 años de su nacimiento. 12 sept. 2008. Dossier Jornada de Homenaje a Simone de Beauvoir. Disponível em: http:// www.simonedebeauvoir.fahce.unlp.edu.ar/. Acesso em: 15 nov. 2009.

FEMENÍAS, María Luisa. Inferioridad y exclusión. Buenos Aires: Grupo Editor Latinoamericano, 1996.

Sobre sujeto y género: lecturas femeinistas de Beauvoir a Butler. Buenos Aires: Catálogos, 2000.

Perfiles del feminismo iberoamericano. Buenos Aires:

Catálogos, 2002. v. 1.

Perfiles del feminismo iberoamericano. Buenos Aires:

Catálogos, 2005. v. 2.

Perfiles del feminismo iberoamericano. Buenos Aires:

Catálogos, 2007a. v. 3.

El género del multiculturalismo. Bernal: UNQui, 2007b.

FEMENIIAS, María Luisa; OLIVER, Amy. Feminist Philosophy in Latin America and Spain. New York: Rodopi, 2007. (Series Philosophy in Latin America).

FEMENÍAS, María Luisa; SÁNCHEZ, Elida Aponte. Articulaciones sobre la violencia contra las mujeres. La Plata: Edulp, 2008. 